\title{
STAR CLUSTERS
}

Edited by JAMES E. HESSER
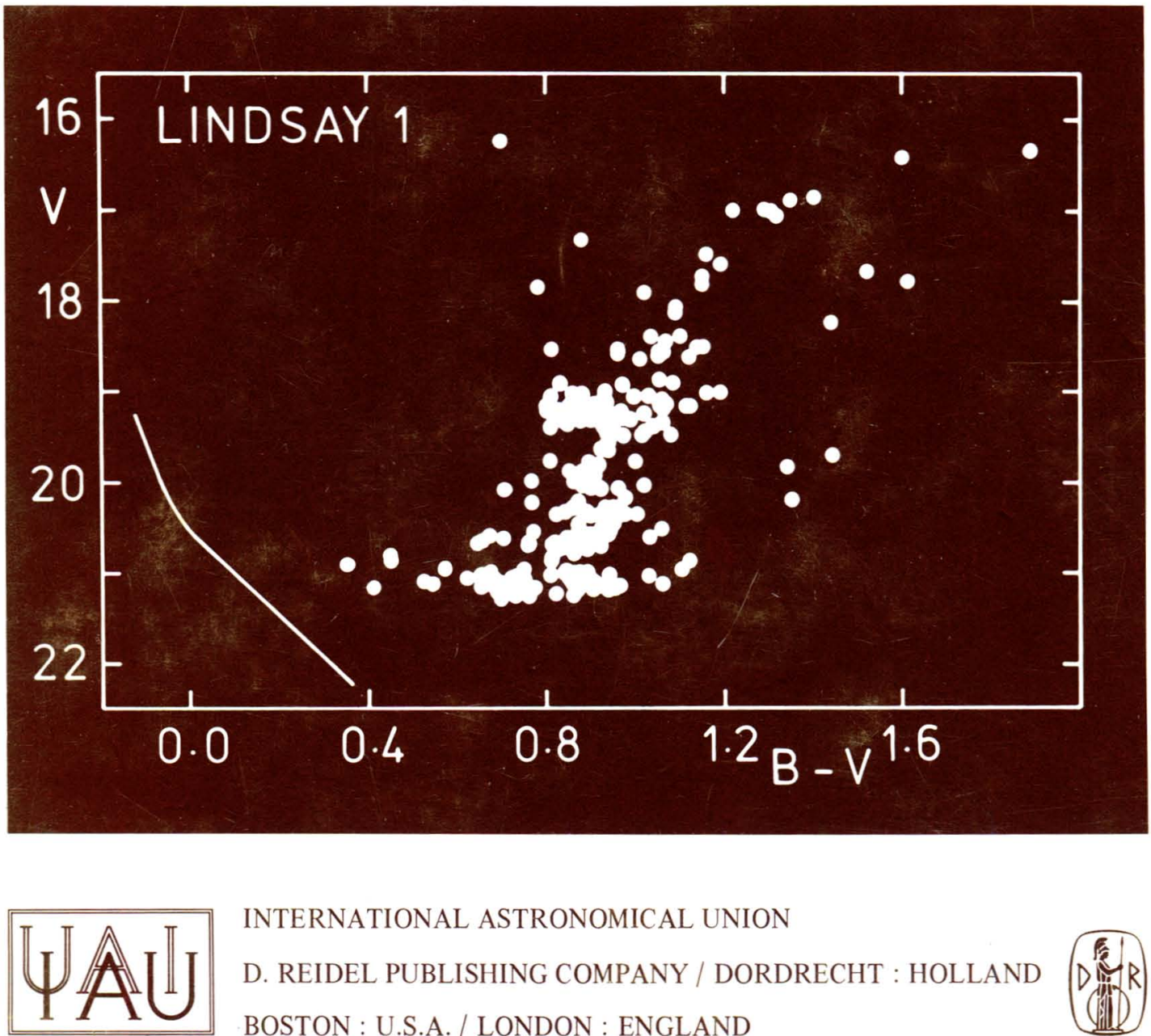

INTERNATIONAL ASTRONOMICAL UNION

D. REIDEL PUBLISHING COMPANY / DORDRECHT : HOLLAND BOSTON : U.S.A./ LONDON : ENGLAND 
This volume contains the proceedings of an I.A.U. meeting held in Victoria, Canada, during August 1979. A hundred and twenty scientists from 23 countries attended the meeting, and the volume comprises 22 review papers, 65 short contributions and summarization of discussion. Many aspects of observational and theoretical cluster research where rapid progress is being made are summarized in the proceedings, and numerous avenues for future work are identified. Among the topics addressed are: associations and galactic structure, ages and abundances in associations, open and globular star clusters, the galactic distance scale from the hyades and globular star clusters, dynamics of open and globular clusters, formation of star clusters, binary stars in clusters, the young and old clusters in extragalactic systems. A major revision of the globular cluster abundance scale which has been in use for many years, is also suggested in the volume.

\section{Audience}

Because cluster studies touch on so many areas of stellar, galactic and extragalactic astronomy and astrophysics, the proceedings should be of interest to a wide astronomical readership. 
STAR CLUSTERS 
INTERNATIONAL ASTRONOMICAL UNION

UNION ASTRONOMIQUE INTERNATIONALE

SYMPOSIUM No. 85

HELD IN VICTORIA, B.C., CANADA, 27-30 AUGUST, 1979

\section{STAR CLUSTERS}

EDITED BY

JAMES E. HESSER

Dominion Astrophysical Observatory,

Herzberg Institute of Astrophysics,

Victoria, B.C., Canada

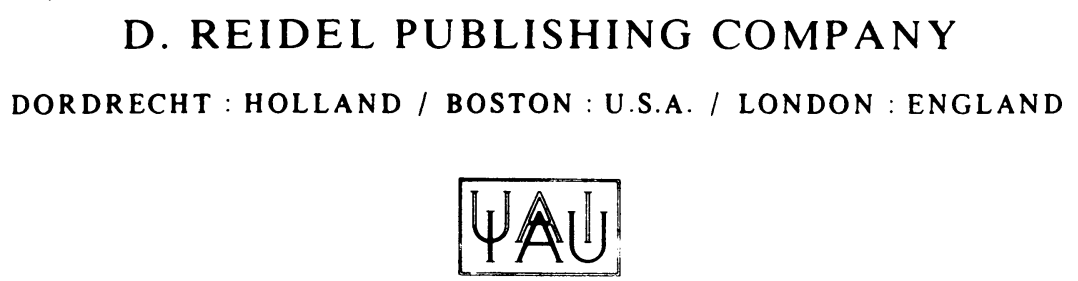

D. REIDEL PUBLISHING COMPANY 


\section{Library of Congress Cataloging in Publication Data}

Main entry under title:

Star Clusters

(Symposium -- International Astronomical Union: No. 85)

(Proceedings of a Symposium) held in Victoria, B.C. Canada, 27-30 August, 1979.

Includes index.

1. Stars-Clusters-Congresses. I. Hesser, J. E. II. Series: International Astronomical Union. Symposium; No. 85.

QB853.S73 523.8'5 80-11856

ISBN 90-277-1087-2

ISBN 90-277-1088-0 pbk.

\section{Published on behalf of \\ the International Astronomical Union}

by

D. Reidel Publishing Company, P.O. Box 17, 3300 AA Dordrecht, Holland

\section{All Rights Reserved}

Copyright $\odot 1980$ by the International Astronomical Union

Sold and distributed in the U.S.A. and Canada

by Kluwer Boston Inc., Lincoln Building,

160 Old Derby Street, Hingham, MA 02043, U.S.A.

In all other countries, sold and distributed

by Kluwer Academic Publishers Group,

P.O. Box 322, 3300 AH Dordrecht, Holland

D. Reidel Publishing Company is a member of the Kluwer Group.

No part of the material protected by this copyright notice may be reproduced or utilized in any form or by any means, electronic or mechanical, including photocopying, recording or by any informational storage and retrieval system, without written permission from the publisher

Printed in The Netherlands 
PREFACE

CONFERENCE PHOTOGRAPH (Frontispiece)

ACKNOWLEDGEMENTS

LIST OF PARTICIPANTS

xiii

AUGUST 27

INTRODUCTION, ASSOCIATIONS, GALACTIC STRUCTURE

Sidney van den Bergh

STAR CLUSTERS AS TOUCHSTONES FOR THEORIES

OF GALACTIC EVOLUTION - A FEW EXAMPLES

Gösta Lyngá

CLUSTERS, ASSOCIATIONS AND GALACTIC STRUCTURE

William Herbst

RECENT RESULTS ON ASSOCIATIONS:

ANATOMY OF CMa OB1 AND Mon OB1

Poul E. Nissen

ABUNDANCE VARIATIONS AMONG YOUNG CLUSTERS

AND ASSOCIATIONS

Robert B. Hanson

THE HYADES CLUSTER DISTANCE

William E. Harris

THE GALACTIC DISTANCE SCALE:

GLOBULAR CLUSTERS

G. Cayrel de Strobel

HYADES DISTANCE AND CHEMICAL COMPOSITION FROM THE

COMPETITIVE USE OF ASTROMETRY, PHOTOMETRY, SPECTRO-

SCOPY, AND INTERNAL STRUCTURE COMPUTATION

E.E. Baart, G. de Jager, P.I. Mountfort

$2.3 \mathrm{GHz}$ RADIO EMISSION FROM ScO OB2

C. Chiosi, G. Bertelli, E. Nasi

MASSIVE STARS: EVOLUTION WITH MASS LOSS. III.

LOW METAL STARS, AND WR'S IN SMC 
C. Chiosi and F. Matteucci

CHEMICAL EVOLUTION OF THE GALACTIC DISK. II.

GRADIENTS OF CHEMICAL COMPOSITION

D.L. Crawford

OPEN CLUSTER ANALYSES AT KPNO

O.B. Dluzhnevaskaya, A.E. Piskunov,

S.V. Vereshchagin

RATE OF ENRICHMENT OF THE GALACTIC DISC WITH METALS

FROM DATA ON OPEN CLUSTERS

A. Feinstein

SOME RESULTS CONCERNING THE OB AGGREGATE AROUND

ETA CARINAE

P.J. Flower

THE HYADES CLUSTER - SOLAR METALLICITY?

Lars 0lof Lodén

HIDDEN CLUSTERS IN THE SOUTHERN MILKY WAY

Gösta Lyngà and Ingemar Lundström

A COMPUTER BASED CATALOGUE OF OPEN CLUSTER DATA

H.M. Maitzen, A.F.J. Moffat,

Th. Schmidt-Kaler

GALACTIC ROTATION FROM YOUNG OPEN STAR CLUSTERS

J . C. Mermilliod

THE PRESENT DATA SITUATION FOR STARS IN OPEN CLUSTERS. II.

J. Meurers

THE STRUCTURE OF $h$ AND $\times$ PERSEI

J. Ruprecht, B.A. Balázs, R.E. White

SUPPLEMENT 1 TO THE SECOND EDITION OF

THE CATALOGUE OF STAR CLUSTERS AND ASSOCIATIONS 


\section{AUGUST 28}

OPEN CLUSTERS

Ivan R. King

THE DYNAMICS OF OPEN CLUSTERS

Floor van Leeuwen

MASS AND LUMINOSITY FUNCTION OF THE PLEIADES

Elena Terlevich

$N$-BODY SIMULATIONS OF OPEN CLUSTERS

165

G. Burki

FORMATION OF OPEN CLUSTERS

J.P. Vader

DYNAMICAL HISTORY OF THE SOLAR NEIGHBOURHOOD

Gretchen L.H. Harris

OPEN CLUSTERS AND STELLAR EVOLUTION

A. Maeder, J.C. Mermilliod

OPEN CLUSTERS AS TESTS OF STELLAR EVOLUTION

M. Buchholz, Th. Schmidt-Kaler

DYNAMICAL AGE DETERMINATION OF OPEN CLUSTERS

C.A. Christian

DISTANT GALACTIC OPEN CLUISTERS

A. Feinstein

STARS WITH ABNORMAL SPECTRA IN OPEN CLUSTERS

M. Pim FitzGerald, G.L.H. Harris, M. Miller

A SPECTROSCOPIC AND STATISTICAL STUDY OF COLLINDER 140

M. Grenon

METAL ABUNDANCES OF YOUNG STELLAR GROUPS

S.M. Hassan, A.I. Othman

A NEW PHOTOMETRIC INVESTIGATIO" OF TUE YNING OPFN CLUSTER NGC 663

James E. Hesser, Horace A. Smith

SPECTROSCOPIC AND PHOTOMETRIC OBSERVATIONS OF THE

SOUTHERN, INTERMEDIATE-AGE CLUSTERS NGC 2477 AND

NGC 2660 
Hugo Levato, Stella Malaroda

SPECTRAL MORPHOLOGY IN THE OPEN CLUSTER NGC 2287

H.G. Marraco, J.C. Forte

POLARIZATION OF STARS IN THE FIELD OF NGC 3372

M. Mayor, J.-C. Mermilliod

RADIAL VELOCITIES AND ROTATIONAL VELOCITIES OF LATE-

TYPE STARS IN THE COMA BER CLUSTER

J.C. Mermilliod

COMPARATIVE STUDY OF YOUNG OPEN CLUSTERS: AGE

DETERMINATION AND STELLAR CONTENT

C.A. Olano, W.G.L. Pöppe1, M.D. Vota

A SEARCH FOR HI IN NINE SOUTHERN GALACTIC CLUSTERS

E.S. Parsamian

FLARE STARS IN EVOLVED CLUSTERS

R. Rajamohan, Ashok K. Pati

SUPERNOVAE AND THE AP PHENOMENON

R.R. Shobbrook

ANOMALIES IN THE UVbYB PARAMETERS OF YOING OPEN CLUSTERS

A.R. Upgren, E.W. Weis

PHOTOMETRY OF THE LOWER MAIN SEQUENCES OF NEARBY CLUSTERS

AUGUST 29

OPEN AND GLOBULAR CLUSTERS

Virginia L. Trimble

BINARY STARS IN GLOBULAR AND OPEN CLUSTERS

Pierre Demarque

AGES AND ABUNDANCES OF GLOBULAR CLUSTERS AND THE

OLDEST OPEN CLUSTERS

S.C.B. Gascoigne

THE OLDER CLUSTERS IN THE MAGELLANIC CLOUDS

K.C. Freeman

LMC CLUSTERS: YOUNG 


\section{S.J. Aarseth}

DYNAMICS OF INITIAL BINARIES IN OPEN CLUSTERS

\section{P. Brosche, M. Hoffmann}

WIDE BINARIES IN THE PLEIADES

Bruce W. Carney

GLOBULAR CLUSTER AGES AND DISTANCES

F.D.A. Hartwick, A.P. Cowley

GLOBULAR CLUSTERS IN THE LMC

M.W. Feast, C. Black

THE CLUSTER NGC 330 IN THE SMC: RADIAL VELOCITIES

OF INDIVIDUAL STARS

E.H. Geyer, U. Hopp, M. Kiehl, S. Witzigmann

STAR DENSITY DISTRIBUTION IN YOUNG AND OLD GLOBULAR

CLUSTERS OF THE LARGE MAGELLANIC CLOUD

Eduardo Hardy, Jorge Melnick, Claude Reheault SOME COLOR-MAGNITUDE DIAGRAMS AND ABUNDANCES IN THE MAGELLANIC CLOUDS

James E. Hesser, James M. Nemec, Patricio Ugarte P. MAGELLANIC CLOUD HALO RR LYRAE STARS :

THE NGC 2257 FIELD IN THE OUTSKIRTS OF THE LMC

Kenneth A. Janes, Bruce W. Carney

THE SMC CLUSTER NGC 330

William E. Kunkel

PHOTOMETRIC STUDIES OF THE EXTREME SMC WING

Martha H. Liller

A SEARCH FOR MAIN-SEQUENCE BINARIES IN GLOBULAR CLUSTERS

J. -C. Mermilliod, M. Mayor

MEMBERSHIP AND BINARITY OF RED GIANTS IN OPEN CLUSTERS

DETERMINED BY PHOTOELECTRIC RADIAL VELOCITIES

John M. Retterer

THE BINDING-ENERGY DISTRIBUTION OF THE BINARIES IN A STAR CLUISTER

Merle F. Walker

ELECTRONOGRAPHIC PHOTOMETRY OF STAR CLUSTERS IN THE 
AUGUST 30

GLOBULAR CLUSTERS

René Racine

GLOBULAR CLUSTER SYSTEMS IN GALAXIES

369

Judith G. Cohen

CHEMICAL PROPERTIES OF INDIVIDUAL GLOBULAR CLUSTERS

385

Douglas C. Heggie

DYNAMICS AND EVOLUTION OF GLOBULAR CLUSTERS

401

Alberto Di Fazio, Alvio Renzini

A NEW SCENARIO FOR THE FORMATION OF GLOBULAR CLUSTERS

AND THEIR PECULIARITIES

G. Alcaino

THE GLOBULAR CLUSTER NGC 6144 AND ITS NEIGHBOURING REGION

Gonzalo Alcaino, William Liller

THE MAIN SEQUENCE OF THE VERY OLD GLOBULAR CLUSTER

NGC 63.97

Peter J. Andrews

VARIABLES IN NGC 4590

C. Cacciari, K.C. Freeman

CALCIUM ABUNDANCE IN THE RR LYRAE STARS IN NGC 3201 AND M5

R.D. Cannon

RECENT RESULTS ON THE TURN-OFF OF $\omega$ CENTAURI

Kyle M. Cudworth

PROPER MOTION STUDIES OF GLOBULAR CLUSTERS

D.J. Faulkner

ACCRETION OF GAS BY STARS IN GLOBULAR CLUSTERS

Jay A. Froge1

INFRARED PHOTOMETRY OF GLOBULAR CLUSTER GIANT STARS:

SOME RECENT RESULTS

P. Giannone, L. Rossi

INWARD DIFFUSION OF HELIUM IN HORIZONTAL-BRANCH

STARS OF GLOBULAR CLUSTERS 
Elizabeth M. Green

GLOBULAR CLUSTER LUMINOSITY FUNCTIONS AND HELIUM

ABUNDANCE DIFFERENCES ACROSS THE GALAXY

441

David A. Hanes, Jean F. Brodie

SPECTRUM SCANS OF GLOBULAR. CLUSTERS IN M87

451

James E. Hesser

EVIDENCE FOR SPECTRAL DIFFERENCES AMONG 47 TUCANAE

TURNOFF-REGION STARS

453

Helen Sawyer Hogg, Amelia Wehlau

VARIABLE STARS IN THE GLOBULAR CLUSTER NGC 6934

455

Gerald E. Kron, Katherine C. Gordon, Anthony V. Hewitt SURFACE BRIGHTNESS PROFILES OF 68 GLOBULAR CLUSTERS

DERIVED FROM ELECTRONIC CAMERA RECORDINGS

Ruth C. Peterson

EVIDENCE FOR PRIMORDIAL INHOMOGENEITIES FROM ABUNDANCE OF GIANTS IN M5, M13, AND M22

A.G. Davis Philip, D.S. Hayes

FUNDAMENTAL TEMPERATURES AND SURFACE GRAVITIES FOR HB

STARS IN THE FIELD AND IN GLOBULAR CLUSTERS

Catherine A. Pilachowski, Christopher Sneden,

R. Canterna

CHEMICAL COMPOSITIONS OF SOUTHERN GLOBULAR CLUSTERS :

47 TUCANAF, NGC 3201, AND NFC 6752

Harvey B. Richer

WHITE DWARF CANDIDATES IN THE GLOBULAR CLUSTER NGC 6752

G. Severne, M. Luwel

DYNAMICAL THEORY OF COLLISIONLESS RELAXATION

Ülo-Illmar K. Veltmann

TWO SIMPLE FORMS OF PHASE DENSITY AND MODELS OF STAR CLUSTERS

R.E. White, S.J. Shawl

AXIAL RATIOS, ORIENTATIONS, AND CENTER COORDINATES

OF GALACTIC GLOBULAR CLUSTERS

K. Zdanavičius, V. Straižys

THE INTEGRATED PHOTOMETRY OF GLOBULAR CLUSTERS IN THE VILNIUS PHOTOMETRIC SYSTEM 
NAME INDEX

OBJECT INDEX 499

SUBJECT INDEX

507 